\title{
A Reply to Ji-Huan He
}

\section{Citation}

Good, I., J. M. Kenoyer, and R. H. Meadow. 2011. A Reply to Ji-Huan He. Archaeometry 53, no. 6: 1257-1258.

\section{Published Version}

doi:10.1111/j.1475-4754.2011.00591.x

\section{Permanent link}

http://nrs.harvard.edu/urn-3:HUL.InstRepos:34611666

\section{Terms of Use}

This article was downloaded from Harvard University's DASH repository, and is made available under the terms and conditions applicable to Other Posted Material, as set forth at http:// nrs.harvard.edu/urn-3:HUL.InstRepos:dash.current.terms-of-use\#LAA

\section{Share Your Story}

The Harvard community has made this article openly available.

Please share how this access benefits you. Submit a story.

Accessibility 
A Reply to Ji-Huan He

Irene Good, Jonathan Mark Kenoyer and Richard H Meadow

We are grateful for the opportunity to hear readers' views concerning our joint paper on archaeological evidence for early silk in the Indus Civilization (Good et al. 2009), and are equally grateful for the opportunity to respond to one particular reader's comments on our findings: Mr. Ji-Huan He (2010), who writes 'Silk is of China and China is of Silk".

First, we wish to clarify a major point. Our article does not argue for a non-Chinese origin for the domestication of silkworms. We reported evidence that silk from wild indigenous forms of silkworm was known in the Indus Civilization at an early date, roughly contemporary to some of the earliest clear archaeological evidence for silk in China.

Mr. He points out that the earliest documentary evidence for silk in China comes from oracle bone inscriptions. These, however, date to the period of the Shang Dynasty (second half of the second millennium BC), which is later than the material discussed in our article. Mr. He also points our attention to depictions of what have been identified as silkworms on a ca. 4900 B.C. engraved ivory basin from late middle Neolithic Hemedu in Zhejiang province. Identifications of such depictions, however, remain interpretations. This carving is not silk, nor is it a depiction of sericulture activity, nor do we yet have extant silk textiles from this site or anywhere else at this early time period.

As for actual remains of silk, our paper cited the original report for the evidence from the Qianshanyang site (Liangzhu Neolithic culture, Yangtze delta, Zhejiang province), from which some early silk textile fragments and other silk remains have been identified (Zhejiang 1960). In addition, there is what may be even earlier silk textile evidence from the Qingtai site (Late Yangshao Neolithic culture, Yellow River valley, Henan province: Zhang and Gao 1999). The Qianshanyang silk is associated with a bamboo basket from the earliest cultural deposits of the site, which have provided three radiocarbon dates with median calibrated values between ca. 3500 and 2700 BC (calBC). However, the identification of sesame (Sesamum indicum) and especially of peanut (Arachis hypogaea) from these deposits, if correct, raises the issue of contextual integrity, because sesame is thought to come from India and peanuts are a South American plant. The silk from Qingtai is associated with cultural remains of the Late Yangshao period, ca. 4000-3500 calBC, but its immediate context has not been radiocarbon dated. As excavations continue on archaeological sites in China, we expect that the beginnings of the use of silk and of sericulture will become more clearly and securely articulated.

Finally, we wish to clearly state that our findings from South Asia in no way diminish the culture history of China and the significance of the development of sericulture there. We strongly believe that scientific research should always be motivated by curiosity and tempered with objectivity. 


\section{References:}

Good, I.L., Kenoyer, J.M., and Meadow, R.H., 2009, New evidence for early silk in the Indus Civilization, Archaeometry 51: 457-66.

He, Ji-Huan, 2010, Silk is of China and China is of silk, Archaeometry (in press).

Zhang Songlin, and Gao Hanyu, 1999, Xingyang Qingtai yizhi chutu sima zhipin guancha yu yanjiu (Observations and research on silk and hemp textiles unearthed from the Qingtai site in Xingyang), Zhongyang wenwu 3: 10-16.

Zhejiang,1960, Wuxing Qianshanyang yizhi dierci fajue baogao (Report on the first and second excavations at the site of Qianshanyang in Wuxing County), Kaogu Xuebao 2: 73-92. 